\title{
PENINGKATAN KEMAMPUAN BAHASA INGGRIS PADA MAHASISWA DI PERHOTELAN DI NUSANTARA COLLAGE DESA PENUJAK KEC. BATU JAI KAB. LOMBOK TENGAH NTB
}

\author{
Danul Aristiawan \\ STIKES Yarsi Mataram \\ danularisetiawan@gmail.com
}

\begin{abstract}
The development of tourism is currently very fast, including tourism on the island of Lombok, many tourist destinations are offered on this island which is nicknamed a thousand mosques, especially those in Central Lombok Regency. The advancement of tourism development in the Central Lombok region is not matched by qualified human resources, especially in mastering foreign languages or English, this is one of the obstacles to improving the quality of service to tourists. Good communication skills, especially using English, are a necessity that everyone who will be involved in the world of tourism, especially those involved in hospitality, must have. For this reason, the implementation of the service can improve communication skills and services provided to tourists both foreign and domestic. The method used in this community service is short courses where the training participants are simulated to receive guests who come from foreign countries, so that from the beginning of this training the participants of this training are accustomed to dealing with guests. As a result of this training, the participants were able to communicate verbally with good enough, where the participants did not feel nervous anymore when communicating with foreign guests. Participants have acquired learning experiences, although not all of them can be practiced intensively. Of course, this learning experience will be one of the assets for them to compete in the world of work which globally demands communication skills in foreign languages.

Keywords: Improvement, Ability, English
\end{abstract}

\begin{abstract}
Abstrak
Perkembangan dunia pariwisata saat ini sangat pesat,tidak terkecuali periwisata yang ada di pulau Lombok, banyak destinasi wisata yang ditawarkan di pulau yang berjuluk seribu masjid ini, khususnya yang ada di Kabupaten Lombok Tengah. Majunya perkembangan pariwisata di kawasan Lombok Tengah tidak diimbangi dengan SDM yang mumpuni terutama dalam penguasaan bahasa asing atau bahasa Inggris, hal ini menjadi salah satu kendala untuk meningkatkan kualtas pelayanan kepada para wisatawan asing. Kemampuan berkomunikasi yang baik terutama menggunakan bahasa Inggris merupakan keniscayaan yang hasrus dimiliki oleh setiap orang yang akan berkecimpung di dunia pariwisata terutama yang berkecimpung di perhotelan. Untuk itu dengan dilaksanakannya pengabdian dapat meninggkatkan kemampuan berkomunikasi dan pelayanan yang diberikan kepada wisatawan baik mancan Negara maupun domestic. Metode yang digunakan dalam pengabdian masyarakat ini yaitu dengan metode short course dimana peserta pelatihan ini di simulasikan untuk menerima tamu yang datang dari mancan Negara, sehingga dari awal pelatihan ini para peserta pelatihan ini dibiasakan untuk berhadapan dengan tamu. Hasil dari pelatihan ini, para peserta sudah mampu berkomunikasi secara verbal dengan ckup baik, dimana para peserta sudah tidak merasa grogi lagi ketika berkominikais dengan tamu mancan Negara. Pengalaman belajar (learning experience) telah didapat oleh peserta walaupun masih belum seluruhnya dapat dipraktikkan dengan intensif. Tentunya, pengalaman belajar ini akan menjadi salah satu modal bagi mereka untuk ikut bersaing di dunia kerja yang secara global menuntut kecakapan berkomunikasi dalam bahasa asing. Kata Kunci:Peningkatan, Kemampuan, Bahasa Inggris
\end{abstract} Accepted: $2020-09-15$ 


\section{Pendahuluan}

Provinsi NTB merupakan salah satu provinsi yang memiliki kemajuan pesat dibidang pariwisata, penegmbangan periwisata di NTB tersebar hamper di semua Kabupaten yang ada di wilayah NTB. Kabutapen Lombok Tengah ditetapkan menjadi salah satu daerah destinasi wisata, dimana Kabupaten Lombok Tengah ditunjuk sebagai salah satu lokasi penyelggaraan event internasional Motto GP 2021, pembangunan sirkuit, penginapan, hotel berbintang tengah di kerjakan oleh pemerintah pusat dan daerah, kemajuan dibidang pariwisata menarik baxak investor asing untuk menamkan modalnya di Lombok Tengah, hotel yang dibangun merupakan peluang besar bagi putra-putri Lombok Tengah untuk berkarir di bidang perhotelan. Di Kabupaten Lombok Tengah tempat-tempat wisata semakin tertata dengan baik, sehingga telah menarik para wisatawan lokal dan mancanegara untuk berkunjung ke tempat-tempat tersebut, seperti: Pantai Kuta, Pantai Seger, Pantai Mawun, dll. Merupakan objek wisata yang sudah dikenal baik di dalam negeri hingga mancanegara. Dengan perkembangan pariwisata yang pesat tersebut membuat pembangunan infrastruktur juga sangat pesat. Pembangunan sirkuit Motto GP, Mandalika Resort menjadikan Kabupaten Lombok Tengah menjadi tujuan destinasi yang mendunia. Pembangunan hotel-hotel berbintang tengah dikerjakan untuk menunjang event internasional tersebut. Hal ini membuka peluang bagi putra-putri daerah Lombok Tengah untuk berkarir di dunia perhotelan.

Besarnya peluang kerja yang akan dibuka di bidang perhotelan akan memberikan dampak positif bagi kemajuan dan kemakmuran masyarakat Lombok Tengah. Namun dengan minimnya pendidikan formal yang membuka jurusan perhotelan akan berdampak pada kurang maksimalnya pemanfaatan SDM putra-putri Lombok Tengah, Nusantara Collage merupakan salah satu lembaga pendidikan yang bergerak dibidang perhotelan , dimana Nusantara Collage membuka program D1 Perhotelan yang telah meluluskan mahasiswa-mahasiswi dan sebagian besar dari alumninya telah bekerja di hotel, travel dll.

Pengembangan tempat-tempat wisata di Kabupaten Lombok Tengah harus pula dibarengi dengan peningkatan sumberdaya manusia, khususnya dalam bidang bahasa Inggris. Saat ini bahasa Inggris masih merupakan bahasa pengantar utama di dunia, sehingga masih dikatakan sebagai International Language. Tidak dapat dipungkiri pembelajaran bahasa Inggris yang diperoleh di SMP dan SMU belum memberikan jaminan bagi outputnya khususnya para pemuda dan pemudi dapat berbicara bahasa Inggris dengan baik. Oleh sebab itu untuk membantu untuk meningkatkan kemampuan bahasa Inggris para mahasiswa D1 Perhotelan di Nusantara Collage di Kabupaten Lombok Tengah, maka dilaksankan pengabdian masyarakat dengan judul "Peningkatan Kemampuan Bahasa Inggris Pada Mahasiswa D1 Perhotelan di Nusantara Collage Desa Penujak Kec. Batu Jai Kab. Lombok Tengah". Kemampuan berbahasa Inggris yang dimaksud adalah keterampilan berbicara bahasa Inggris dalam bentuk percakapan seharihari yang berkaitan dengan pemandu wisata. Pelaksanaan kegiatan ialah dalam bentuk short course. Hal ini dimaksudkan agar setelah selesai mengikuti kursus ini, pengetahuan yang diperoleh bisa segera diterapkan dalam kehidupan nyata yang ditemui di lapangan.

Dengan demikian, pengabdian tersebut kedepannya dapat meningkatkan kemampuan berbicara bahasa Inggris dalam percakapan sehari-hari bagi para mahasiswa perhotelan di Kabupaten Lombok Tengah, pengabdian ini sungguh-sungguh merupakan 
kegiatan yang bersinergi secara positif dan bermanfaat bagi pemerintah daerah dan secara khusus bagi para mahasiswa-mahasiswi yang akan berkarir di bidang pariwisata dan perhotelan di Kab. Lombok Tengah.

\section{Metode}

Program Pengabdian Masyarakat dengan judul "Peningkatan Kemampuan Bahasa Inggris Pada Mahasiswa D1 Perhotelan di Nusantara Collage Desa Penujak Kec. Batu Jai Kab. Lombok Tengah" dilaksanakan dengan mengutamakan prinsip pemberdayaan mahasiswa D1 prhotelan dan masyarakat lokal dengan tujuan utama keberlanjutan program dan kemandirian mahasiswa dan masyarakat. Program ini dilaksanakan dengan cara memberikan short course bahasa inggris pada mahasiswa D1 perhotelan di Nusantara Collage selama 3 bulan.

Dalam minggu pertama peserta pengabdian masyarakat diberikan materi dasar tata cara berkomunikasi yang baik dengan tamu, cara menyambut tamu, cara menyapa, dan cara mempromosikan destinasi wisata yang ingin di kunjungi. Dalam pelaksanaannya peserta akan di bagi menjadi beberapa kelompok sehingga proses short course yang di berikan akan lebih optimal dalam pelaksanaannya. Diharapkan setelah menyelesaikan tahap pertama short course peserta akan mampu berkomunikasi dengan lancar.

Pada bulan ke dua, perserta akan diberikan materi yang lebih spesifik tentang perhotelan, dimana para peserta akan diberikan materi mengenai pembicaraan yang lebih detail kepada tamu, sehingga diharapkan para peserta mampu mempromosikan hotel tempatnya bekerja dan tempat-tempat menarik yang ada di kawasan Lombok Tengah secara khusus dan NTB pada umumnya. Dengan demikian para peserta pengabdian mampu menjaga nama baik hotel dan tempat pariwisata yang menjadi tulang punggung perekonomian masyarakat dengan baik. Diharapkan kedepannya para wisatawan asing akan lebih antusias untuk datang berlibur di Lombok Tengah dan Nusa Tenggara Barat.

Pada bulan ketiga dengan adanya short course bahasa inggris yang baik dan maksimal diharapkan kedepannya para peserta memiliki life skill khususnya dalam mempromosikan daerah wisata yang ada di daerahnya masing-masing, sehingga peluang memperbaiki perekonomian kelurga dan masyarakat dapat di tingkatkan secara maksimal. pelayanan yang maksimal dari semua komponen.

\section{Hasil dan Pembahasan}

Kegiatan pelaksanaan Pengabdian di Nusantara College Desa Penujak sesuai yang ada di lapangan meliputi; 1) Kegiatan inti pelaksanaan short course Bahasa Inggris pada mahasiswa D1 Perhotelan di Nusantaran College, 2) Kegiatan pelaksanaan praktik public speaking pada mahasiswa D1 Perhotelan di Nusantaran College, dan 3) Kegiatan Penunjang lainnya. Untuk kegiatan short course atau pelatihan Bahasa Inggris dibuka bersama secara resmi oleh Ketua dan annggota Tim pembimbing dan Pembina Nusantara College pada hari Sabtu, 23 September 2019. Pelaksanaan pelatihan / short course dimulai Selasa, 25 September 2019. Masing-masing kegiatan tersebut adalah:

Pelataihan / Short Course bahasa Inggrsi bagi mahasiswa D1 Perhotelan di Nusantaran College dilaksanakan pada tanggal 25 September 2019 dengan materi Hotel Reservation, 29 September 2019 dengan materi Hotel Vocabularies, O2 Oktober 2019 
dengan materi Days, Moths, and Years, 06 Oktober dengan materi Hotel Reservation by Calling, 12 Oktober dengan materi Dialogue (Games. Role Play), 18 Oktober 2019 dengan materi Practicing Dialogue ( Games: Role Play), 25 Oktober 2019 dengan materi Check In of the Guest, 02 November 2019 dengan materi Check In of the Guest, 09 November 2019 dengan materi Porfesion, 14 November 2019 dengan materi Days of The Week \&Moths of The Year, 21 November 2019 dengan materi Telling Time, 28 November 2019 dengan materi Reading, 04 Desember 2019 dengan materi Public Speaking (Hotel Promotion 1), 11 Desember 2019 dengan materi Public Speaking (Hotel Promotion 2), 18 Desember 2019 dengan materi Daily Conversation and Speling to the Guest, 23 Desember 2019 dengan materi Understanding the Instruction,.

Kegiatan Public Speaking (English Young Learner) adalah permintaan masyarakat dan pengelola lembaga Nusantara College selanjutnya disetujui Kepala Desa Penujak. Public Spekaing ini ditujukan untuk membantu para mahasiswa D1 Perhotelan untuk mampu berbicara di depan umum tanpa ada rasa grogi, cemas, gemetaran sehingga ketika mereka menjamu tamu hotel mereka bias memberikan pelayanan yang maksimal. Public Speaking ini juga diikuti oleh para tutor yang ada di Nusantara College, tim pengabdian masyarakat menyampaikan cara-cara mengajar pada para tutor.

Kegiatan Penunjang lainnya yang dilakukan oleh tim pengabdian masyarakat adalah: a) Membuat Flash Card (Hotel Vocabularies) untuk membantu peserta didik menghafal dan memahami istilah-istilah perhotelan., b) Merancang dan membuat modul ESP tentang perhotelan.

Pada pelaksanaan kegiatan pengabdian kepada masyarakat ini, antusiasme mahsiswa D1. Perhotelan Nusantara College saat mengikuti pelatihan penggunaan Bahasa Inggris untuk Pariwisata(English for Tourism)ini patut diberikan apresiasi. Pasalnya, peserta kegiatan ini yang berjumlah 10 orang memiliki keinginan sangat serius untuk belajar bagaimana menggunakan Bahasa Inggris untuk berkomunikasi dengan turis dengan setting pariwisata khususnya perhotelan yang ada di Lombok Tenagh. Antusiasme dalam belajar dan mengikuti pelatihan ini menunjukkan bahwa mereka menyadari untuk menjadi pelaku usaha di bidang pariwisata perhotelan saja tidaklah cukup bermodalkan penampilandan finansial. Kemampuan (skill) lainnya yang tidak kalah penting untuk mendukung pasar kerja di aspek pariwisata dibidang perhotelan adalah penguasaan bahasa asing. Hasil yang pertama berkaitan dengan kegiatan mahasiswa mempraktikkan expression greeting and welcoming to tourists seperti yang dipaparkan pada bagian sebelumnya berjalan dengan lancar. Berikutnya, hasil dari pertemuan kedua yang membahas mengenai Hotel Reservation yang berisi ungkapan bertanya dan memberikan informasi kepada turis (asking and giving tourist information). Seperti yang sudah dijelaskan pada bagian sebelumnya bahwa penyampaian materi ini juga berjalan dengan baik. Akan tetapi, mayoritas siswa mengalami kesulitan dalam menggunakan kosakatakosakata (vocabulary)baru yang spesifik dan khusus berkaitan dengan kepariwisataan perhotelan. Hal ini bisa dimaklumi karena berdasarkan informasi yang diberikan oleh staff pengaja, bahwa rata-rata mahasiswa hanya menguasai kosakata Bahasa Inggris yang umum saja. Banyak diantara mereka yang baru mengenal kosakata khusus mengenai kepariwisataan bidang perhotelan ketika mengikuti kegiatan ini. Sebagai bahasa asing resmi di Indonesia,Bahasa Inggris telah masuk ke kurikulum pendidikan sejak di jenjang 
sekolah dasar hingga ke tingkat perguruan tingi.

Hal ini sebagaimana tercantum dalam Lampiran Peraturan Menristekdikti Nomor 70 Tahun 2013 pada halaman 14, pada Kurikulum yang diberlakukan saat ini di Indonesia, mata pelajaran Bahasa Inggris di jenjang perguruan tinggi menjadi MKDU (Mata Kuliah Dasar Umum) dengan alokasi waktu 2 sks. Implikasi dari Kurikulum yang mengalokasikan mata kuliah Bahasa Inggris hanya 2 sks per semester membuat pembelajaran Bahasa Inggris di perguruan tinggi sangat terbatas. Disamping alokasi waktu yang sangat sedikit, materi Bahasa Inggris yang tercantum di silabus Kurikulum juga masih mencakup materi Bahasa Inggris secara umum(general English). Pembelajaran Bahasa Inggris yang berkaitan dengan program keahlian siswa belum diajarkan secara khusus. Oleh karena itu, tim pengabdian kepada masyarakat memberikan motivasi kepada mahasiswa agar terus belajar menambah pengetahuan dan memperkaya kosakata-kosakata Bahasa Inggris dengan memperbanyak bacaan dan referensi.

Hasil berikutnya berkaitan dengan materi Public Speaking. Mahasiswa menunjukkan antusiasme ketika diminta memainkan peran, salah seorang menjadi receptionist di sebuah hotel dan seorang lagi menjadi tourist yang ingin memesan kamar, dengan metode bermain peran para mahasiswa akan lebih termotivasi untuk mempraktikkan bagaimana cara berkomunikasi dengan tamu, hal ini membuat mereka lebih antusias lagi untuk berlatih. Hasil berikutnya yaitu tentang Showing Direction. Kemampuan menunjukan arah kepeda tamu akan sangat bermanfaat bagi mahasisa yang ingin berkarir di pariwiasata khususnya perhotelan, tidak hanya turis lokal yang ingin mengunjungi obyek pariwisata, tetapi juga turis mancanegara memerlukan informasi rinci dari setiap obyek wisata yang dikunjunginya. Hal ini dikarenakan tour itinerary memuat informasi rinci mengenai time and place(waktu dan tempat yang akan dikunjungi), hotel tempat menginap, transportasi yang digunakan, makanan yang disediakan, serta terms and condition(syarat dan kondisi) perjalanan yang akan dilakukan (Pribadi, 2006:33). Oleh karena itu, mahasiswa diberikan pengetahuan mengenai penyusunan Showing Direction. Terakhir, tim pengabdian masyarakat melakukan kegiatan penunjang yaitu dengan membuat Flash Card (Hotel Vocabularies) pembuatan flash card ini akan sangan membantu mahasiswa untuk lebih mudah mengingat atau mengahafal kosa kata baru yang di dapatkan khususnya kosa kata yang berkaitan dengan perhotelan, disamping itu tim juga merancang dan membuat modul ESP tentang perhotelan, dimana modul ini sangat membantu mahasiswa D1 Perhotelan Nusantara College untuk lebih memahami materi-materi pengabdian yang dberikan dan mahasiswa juga bisa berlatih dengan menggunakan modul tersebut sebagai panduan.

Dari kegiatan pengabdian ini mahasiswa dituntut untuk mengetahui obyek pariwisata yang ada di Lombok Tengah sebagai salah satu destinasi wisata, akan tetapi mahasiswa diajak untuk menggali informasi dari sekian banyak tempat yang menarik tersebar di NTB secara umum dan Lombok Tengah khussusnya. Hal ini sejalan dan melekat dengan salah satu muatan pendidikan karakter yg ada pada Kurikulum yaitu cinta tanah air. Salah satu indikator nilai karakter cinta tanah air yang bisa dilakukan oleh mahasiswa adalah menyediakan informasi, baik dari sumber cetak maupun elektronik mengenai kekayaan alam dan budaya di Indonesia (Nurohmah, 2016:41). 
Dengan demikian, mahasiswa tidak hanya semata-mata melatih diri untuk menggunakan Bahasa Inggris dalam bidang perhotelan. Akan tetapi, ada usaha untuk menanamkan nilai-nilai karakter yang positif didapat dengan mengikuti kegiatan ini. Pengalaman belajar yang bisa didapat dari kegiatan ini adalah bahwa berkecimpung di dunia pariwisata khususnya perhotelan membutuhkan ketekunan dan kemauan untuk mempelajari semua hal. Tidak hanya mempelajari seluk beluk mengenai pariwisata (tourism), tempat-tempat wisata (tourism places), agen perjalanan wisata (travelagent), dan hal-hal lainnya berkaitan dengan pariwisata yang lain.

Memiliki keahlian khusus di bidang bahasa juga sangat mutlak diperlukan. Kefasihan berbahasa seringkali menjadi kendala di kalangan para mahasiswa. Masih banyaknya lapisan masyarakat yang menggunakan bahasa ibu untuk berkomunikasi secara formal membuat kefasihan berbahasa Indonesia juga menjadi kendala. Ini terbukti ketika kegiatan pengabdian kepada masyarakat dilaksanakan di Nusantara College. Beberapa mahasiswa terlihat masih menggunakan bahasa ibu untuk berkomunikasi secara formal dengan pengajar di lingkungan lembaga. Bahasa Inggris pun belum sepenuhnya mahasiswa mau menggunakan Bahasa Inggris tersebut untuk berkomunikasi. Berdasarkan contoh kecil tersebut, kemampuan berbahasa, baik menggunakan bahasa Indonesia maupun bahasa asing, menjadi sesuatu yang penting untuk dipelajari mahasiswa sebagai sarana untuk mendukung komunikasi di dunia kerja nantinya. Disamping lancarnya kegiatan ini, masih terdapat beberapa hal yang perludi evaluasi . Alokasi waktu yang terbatas dirasa kurang untuk memberikan kesempatan kepada siswa mempraktikkan penggunaan Bahasa Inggris untuk kepariwisataan khususnya perhotelan lebih intensif. (Tahoma, 11pt, spasi 1,15).

\section{Kesimpulan}

Melaksanakan pengabdian untuk meningkatkan kualiatas sumber daya manusia yang ada di Nusantara College Desa Penujak, Kec. Batu Jai, Kab. Lombok Tengah. melalui pelatihan untuk menguasai dan menggunakan keterampilan berbicara ESP (English for Specific Purposes) pada mahasiswa D1 Perhotelan Nusantara College merupakan kegiatan yang sangat bermakna baik bagi tim pelaksana kegiatan maupun bagi mitra. Bagi tim pelaksana kegiatan, melaksanakan pelatihan Bahasa inggris ESP (English for Specific Purposes) pada mahasiswa D1 Perhotelan Nusantara College merupakan tantantang. Disamping itu, kesabaran dan kreatifitas tim pengajar sangat diperlukan dalam mengelola dan mempertahankan semangat belajar peserta didik.

Penggunaan Bahasa Inggris untuk pariwisata (English for Tourism) yang telah dilaksanakan di Nusantara College menjadi salah satu implementasi kegiatan Tri Dharma Perguruan Tinggi. Mata Kuliah Bahasa Inggris yang alokasi waktunya masih terbatas diajarkan di jenjang perguruan tinggi, memungkinkan untuk memberikan pelatihan Bahasa Inggris yang lebih khusus kepada mahasiswa sesuai dengan Program Keahlian mereka. Antusiasme mahasiswa sebagai peserta pelatihan menunjukkan bahwa mereka sedang mempelajari sesuatu yang baru, yang secara khusus belum diajarkan secara mendalam di kampus. Pengalaman belajar (learning experience) telah didapat oleh mahasiswa walaupun masih belum seluruhnya dapat dipraktikkan dengan intensif. 
Tentunya, pengalaman belajar ini akan menjadi salah satu modal bagi mereka untuk ikut bersaing di dunia kerja yang secara global menuntut kecakapan berkomunikasi dalam bahasa asing.

\section{Daftar Pustaka}

Aristiawan, D. (2018). Multilingual code mixing in Sasak language in Karang Buyuk Ampenan. JOLLT Journal of Languages and Language Teaching, 6(1), 61-66. https://doi.org/10.33394/jollt.v6i1.814

J. R. Searle. (1986). Speech Act Theory. Oxford: Oxford University Press

Baker, Mona. 2001. Routledge Encyclopedia of Translation Studies. London and New York: Routledge

Dörnyei, Zoltán. 2005. The Psychology of the Language Learner: Individual Differences in Second Language Acquisition. New Jersey, USA: Lawrence Erlbaum Associates, Inc.

Catherine, marshall and Gretchen Rosman. (1995). Design Qualitative Research. London University: London

Gardner, R.C. \& Lambert, W. E. 1959. Motivational Variables in Second Language Learning. Canadian Journal of Psychology, 13, 266-272.

Gardner, Robert C. 1985. Social Psychology and Second Language Learning: The Role of Attitudes and Motivation. London: Edward Arnold.

Gardner, Robert C. 2001. Integrative Motivation and Second Language Acquisition. dalam Zoltán Dörnyei \& Richard Schmdt (Eds). Motivation and Second Language Acquisition (hal. 1-19). Hawai, USA; University of Hawai'i Press.

Grice, H. P. (2004). Logic and Conversation.Cambridge; Harvard University Press.

Huda, S. (2013). An Analysis of Conversational Implicature of Native and Non-native Guests in CNN Interview Script. University of Muria Kudus: Kudus.

Hurford, James R. (1983). Semantic of Coursebook. New York: Cambridge University Press.

Lakawa, Agustin Rebecca. 2007. Revisiting Motivation in ESP Mass Education (An Action Research Study at Trisakti University in Jakarta-Indonesia). Disertasi PhD dalam bidang Linguistik Terapan pada School of Languages and Comparative Cultural Studies, the University of Queensland, Australia.

Sanjaya, Wina. 2010. Strategi Pembelajaran Berorientasi Standar Proses Pendidikan. Jakarta: Kencana

Saj, H. E.(2012). Discourse Analysis: Personal Pronouns in Oprah Winfrey Hosting Queen Rania of Jordan. International Journal of Social Science and Humanity, Vol. 2, No. 6, P. 530: Lebanon.

Tsuda, S. (1993). Indirectness in Discourse: What does it do in conversation?. Intercultural communication studies III: Tokaigakuen

Wangling.(2010). Analysis of conversational implicature in Chinese talk show from cooperative principle.Wuhan University of Technology: China

Yule, G. (2006). The study of language. (3rdEd.). New York, NY: Cambridge University Press. 